\title{
POSITION
}

\section{VOLDSUDØVERES TEKNOLOGISKE SNILDE}

Mikroovervågning, digital vold og kønsteknologi

\section{BO WAGNER SØRENSEN}

Siden 2000 har der blandt praktikere og forskere været stigende opmærksomhed på digital vold, herunder digital vold som et integreret aspekt af vold i parforhold. Mange voldsudøvere tager nemlig teknologien til hjælp i deres mikroovervågning af partneren, og det gælder især mandlige voldsudøvere (EIGE 2017). Mænd viser sig at være ret kompetente, når det drejer sig om hjælpemidler til den brug. I EIGE's rapport „Digital vold mod kvinder og piger“ advares mod at opfatte digital vold som et fænomen, der er adskilt fra vold i den virkelige verden. Det nævnes for eksempel, at ekspartneres cyberstalking følger samme mønster som fysisk stalking og derfor kan ses som partnervold, som blot er faciliteret af teknologi. Det er i øvrigt en kendsgerning, at stalking i forbindelse med opløste parforhold overvejende er noget, mænd bedriver (se fx Johansen, Tjørnhøj-Thomsen \& Helweg-Larsen 2013; Jørgensen 2013:10).

De fleste mennesker forbinder umiddelbart vold i parforhold med fysisk vold, selv om der er tale om et fænomen med mange forgreninger og understøttende elementer. I både voldsforskningen og på kvindekrisecentrene har man i mange år opereret med flere voldsformer, herunder fysisk, psykisk, seksuel og økonomisk vold, som er de mest anerkendte. Nogle krisecentre omtaler også materiel vold, digital vold og stalking, ${ }_{1}^{1}$ men typisk omfattes materiel vold definitorisk af økonomisk vold og de to andre af psykisk vold. At der er mange voldsformer i spil, understreger, at volden ikke alene handler om fysiske overgreb.

Voldsformerne udspringer af praktikeres og voldsforskeres erfaringer med, at vold mod kvinder i parforhold er et komplekst fænomen med forgreninger til alle aspekter af livet. Disse erfaringer har udmøntet sig i internationalt anerkendte definitioner. I FN's definition af vold mod kvinder indgår skadelige handlinger af ikke bare fysisk, men også seksuel og psykisk karakter samt trusler om samme, herunder tvang og frihedsberøvelse. EIGE, som står for Det Europæiske Institut 
for Ligestilling mellem Mænd og Kvinder, tager udgangspunkt i Istanbul-konventionens definition af vold mod kvinder, der opererer med, at volden har fire hovedformer: fysisk, seksuel, psykologisk og økonomisk vold.

Når volden splittes op i diverse former, kan man risikere, at de får deres eget liv. Selv om voldsformerne oprindeligt er udsprunget af en indsigt i voldens kompleksitet, og hvordan de forskellige aspekter eller voldsformer spiller sammen, overses denne indbyrdes sammenhæng af og til. Når volden først er ,sat på former", ses undertiden en fastfrysning af formerne $\mathrm{i}$ isolerede typologier.

\section{Voldens opsplitning og typologisering}

Tendensen til at splitte volden op i distinkte typer ses blandt andet hos Socialstyrelsen, som har til opgave at tilvejebringe ny socialfaglig viden og også er en central aktør inden for området vold i nære relationer. På styrelsens hjemmeside kan man læse følgende under overskriften „Typer af vold“:

Vold i familien kan være både fysisk og psykisk. Selvom psykisk vold foregår mere skjult, kan den være lige så skadelig som fysisk vold. Næsten alle, der er udsat for vold, er udsat for flere former for vold samtidig. Men volden kan også være en enkeltstående handling (Socialstyrelsen 2019a).

Det fremgår imidlertid af en af Socialstyrelsens nyere publikationer, at:

Viden om vold og vold i nære relationer er generelt et underbelyst område. [...] Volden forekommer på tværs af køn, kulturer og socialøkonomiske samfundslag og kan komme til udtryk som enten fysisk, psykisk, seksuel, materiel og/eller økonomisk vold (Socialstyrelsen 2020:5; min kursivering).

Et andet og mere udfoldet eksempel er den seneste årsstatistik baseret på oplysninger fra landets cirka 50 krisecentre. Her foretager Socialstyrelsen en opgørelse af antal kvinder udsat for seks forskellige typer af vold: fysisk vold, psykisk vold, seksuelle overgreb, materielle ødelæggelser, økonomisk kontrol og andet, som rummer for eksempel stalking og digital vold (Socialstyrelsen 2019b). ${ }^{2}$ Eller rettere, der måles ikke på unikke kvinder, men på krisecenterophold, da nogle kvinder kan have været på krisecenter flere gange i løbet af året.

I årsstatistikken anvendes disse etablerede „voldstypologier“ efterfølgende til såkaldt temanalyse, hvor man kombinerer voldstype med andre spørgsmål. Resultatet bringes i tre statistiske figurer i form af søjlediagrammer (op.cit.2628). Den første viser, hvor længe kvinderne har været udsat for vold i voksenlivet i forhold til voldstype. Den anden viser, hvor længe kvinderne opholder sig på krisecenter i forhold til voldstype. Den tredje viser, hvilke kvinder der i højere 
grad flytter tilbage til voldsudøveren efter krisecenterophold målt i forhold til, hvilken voldstype de er udsat for.

Socialstyrelsen prøver med andre ord at vise, hvilken voldstype der er mest økonomisk belastende, og hvilken type der er vanskeligst at slippe ud af (og dermed også ultimativt mest økonomisk belastende). Problemet er imidlertid, som det også fremgår af årsstatistikken, at den enkelte kvinde, der er blevet spurgt om sine voldserfaringer, kan have angivet mere end en voldsform og derfor kan være talt med i flere typologier (op.cit.5).

Eksemplet viser, at når voldsformerne først er etableret, bliver de også brugt til noget, selv om brugen kan være misvisende. Den administrative teknologi gør det muligt. Voldsformerne, der oprindeligt var tænkt som en anskueliggørelse af voldens kompleksitet, bruges administrativt til at splitte fænomenet op i isolerede, håndterbare typer, der kan forventes omsat til forskellige politiske tiltag. Man kan undre sig over de nævnte voldstypologier og temaanalyser, når det $\mathrm{i}$ forskningslitteraturen er godt og grundigt beskrevet, at det typisk er den samlede belastning af volden i sin totalitet, der fastholder kvinder i voldelige forhold (Kelly 1987; Lundgren 1993, 1998, 2004; Holmberg \& Enander 2004; Stark 2007; Sørensen 2013).

Som borger eller fagperson skal man ikke forvente at finde en kortfattet, overordnet beskrivelse af fænomenet vold i parforhold på Socialstyrelsens hjemmeside eller et opslagsord som kønsbaseret vold. Derimod kan man finde opslagsordene „Indbyrdes vold“ og „Mænd der lever med partnervold“, idet styrelsen anlægger et kønsneutralt perspektiv (se Sørensen 2019; Sørensen, DanneskioldSamsøe \& Sørensen 2019). ${ }^{3}$

\section{Kvindekrisecentres erfaring med digital vold}

Der var en del mediefokus på de danske krisecentererfaringer med digital vold i 2017-2018. Det afspejler givetvis identifikationen af nye, konkrete problemstillinger i krisecentrenes arbejde, men skal nok også ses i sammenhæng med en øget generel interesse for digitale krænkelser i det nordiske og europæiske kønsligestillingsarbejde (fx EIGE 2017).

I 2017 blev lederen af Kolding Krisecenter interviewet til Jydske Vestkysten om problemet med digital vold på krisecentrene:

Digital vold er en ny og stigende udfordring for os. Volden lægger et ekstra lag på kvindens følelse af at være forfulgt. Det er en meget uhåndgribelig overvågning af kvinden, og negative beskeder kan komme døgnet rundet. Vi bliver nødt til at være langt $i$ arbejdet med at forebygge digital vold, for vi ser hele tiden nye måder, som ekskærester forfølger kvinder elektronisk på (Britt Malkiel Nielsen i Juul 2017). 
Det fremgår af avisartiklen, at lederen har mødt kvinder, der dagligt er blevet terroriseret af flere hundrede trusler og ubehagelige beskeder på Facebook, SMS og Messenger. Når kvinderne flytter ind på krisecentret, er der typisk tale om, at de går i skjul for eksmanden, som derfor ikke skal kunne opspore adressen. På krisecentret foretager de en risikovurdering som noget af det første, og hvis kvinden er i fare, opfordres hun til at koble sig af alt, der kan føre til, at eksmanden finder hende: Telefonen skal have et nyt simkort, Facebook-profilen skal sløjfes, og hun skal have en ny bankkonto, så eksmanden ikke kan gå ind på en fælles netbank og se på kontoudtoget, hvor hun har hævet penge. Eventuelle børn er også involveret:

Er kvinden taget af sted sammen med børn, så skal deres telefoner også tjekkes. Her kan der være koblet en funktion til, så man via telefonen kan finde børnene. Mange af de forskellige devices er lavet for at blive brugt til noget godt, men de kan også blive brugt negativt og ulovligt (Britt Malkiel Nielsen i Juul 2017).

I 2018 blev lederen af Fredericia Krisecenter interviewet om samme problem til Fyens Stiftstidende:

Den psykiske vold er altid til stede. Det starter psykisk og bliver fysisk. Det er ofte på de digitale platforme, den psykiske vold starter [...] Kvinderne modtager trusler på SMS, og nogle oplever, at partneren spreder løgne om dem på Facebook eller opretter falske profiler i deres navn. Kvinderne fortæller også, at de skal filme, hvor de er, og at de skal dokumentere alt, de foretager sig - og det har de jo mulighed for i dag. De, der gerne vil kontrollere, har kronede dage (Bente Hedemann i Nydahl 2018).

Artiklen omtaler digital vold som en af de nyere former for psykisk vold, og det understreges, at den digitale udvikling har givet voldsudøvere helt nye muligheder for at forfølge, overvåge og kontrollere deres partner:

Kvinderne skal stå til rådighed 24 timer i døgnet, og tager man ikke telefonen, bliver man straffet. Mange af de voldsramte kvinder får PTSD, fordi de er i alarmberedskab hele tiden [...]. I den type forhold er det ofte sådan, at parret skal gøre alt sammen. Så har man fælles NemKonto, deler nøglekort og giver sin kode til Facebook. Intet er privat. Når der så sker et brud, så har man lukket den anden ind. Når kvinderne kommer til os, laver vi derfor en sikkerhedsscreening. Vi får spærret deres bankkonto, bestilt nyt NemID, lukket deres Facebook eller ændret koden. Vi bestiller nyt simkort til mobilen og tjekker både kvinden og børnenes mobil og iPad for GPS-signaler, og om man kan finde frem til dem via find min iPhone (Bente Hedemann i Nydahl 2018).

I foråret 2018 foretog DR Nyheder en rundspørge blandt landets krisecentre, som bekræftede problemet med ,digitale krænkelser“. Det fremgår, at det især 
er sager om læsning af den tidligere partners korrespondancer, digital sporing af mobiltelefonen, hacking af profiler på sociale medier samt overvågning via GPS og deling af krænkende materiale, som krisecentrene støder på (Jensen, Bengtsen \& Olhoff-Jakobsen 2018).

\section{Forskningserfaring med mikroovervågning og teknologi}

Digital overvågning blev nævnt af flere af de kvinder, jeg og to kolleger interviewede i forbindelse med forskningsprojektet „Vold mod kvinder i etniske minoritetsfamilier“" (Danneskiold-Samsøe, Mørck \& Sørensen 2011), ${ }^{4}$ selv om vi ikke havde fokus på netop det aspekt, men havde bedt kvinderne om at fortælle deres voldshistorie med egne ord og i eget tempo. En af kvinderne berettede om sin eksmand:

Jeg har altid dækket over ham, for han havde virkelig så meget kontrol over mig ... Når han var ude, optog han mig. Da jeg fandt ud af det, fik jeg et chok. Det var via computeren, han optog min stemme. Det var et særligt program, hvor computeren ikke behøver at være tændt. Når han var ude og drikke og grille kød med sine venner, så optog han min stemme. Det vil sige, at han konstant 24 timer i døgnet holdt øje med mig.

Også i forbindelse med mit forskningsprojekt „Voldsfortællinger og voldsforståelser" fortalte flere af de interviewede kvinder mig uopfordret om (eks)mandens digitale overvågning. ${ }^{5}$ En af kvinderne nævnte blandt andet, at hendes mand på et tidspunkt intensiverede kontrollen, forbød hende at tale med nogen og satte en GPS-overvågning $\mathrm{i}$ hendes telefon. Samtidig spærrede han hende inde i huset og tog nøglen med, når han gik på arbejde (se Sørensen 2013). Han kom hjem og tjekkede hende i frokostpausen.

I interviewet nævner kvinden selv, at hun har været udsat for psykisk og fysisk vold, men mest psykisk. Hendes fortælling er en fortælling om en stadig større indsnævring af liv og råderum:

Han begyndte at skifte min garderobe ud ... Jeg måtte ikke gå i nederdel på arbejde. Skulle i hvert fald have trøjer på, der gik ned over albuen. Måtte ikke gå på stranden. Måtte ikke se veninderne. Måtte ikke gå i biografen med dem og tage på café, alt det, jeg havde gjort før. Måtte ikke gå til ridning. Det blev sådan mere og mere snævert ... men jeg tænkte: Nåh ja, det er nok også bare, fordi han passer på mig. Det fik han jo overbevist mig om.

Kvinden fremhæver især den psykiske vold og fortæller fra tiden, før hun blev spærret inde, at ,han kunne flippe helt ud, hvis der ikke var klinisk rent, når han kom hjem fra arbejde, så jeg måtte afspadsere og tage hjem $\mathrm{i}$ frokosten for at 
vaske gulve“. Der har også været tale om seksuel vold: „Ja, ja, selvfølgelig, det var en del af det hele.“ Og der har været tale om økonomisk vold. Han rådede over hendes hævekort og gav hende kontanter, som hun skulle redegøre for ved fremvisning af kvitteringer. Hun fortæller, hvordan hun tidligere var handlekraftig, men efterhånden er svundet ind til ingenting fysisk og psykisk. Hun er med andre ord blevet udvisket, har mistet sig selv, sin personlighed (jf. Lundgren 2004; Stark 2007).

\section{Fra digital vold til kønsteknologi}

Som det fremgår af interviewmaterialet, kan en voldsudøver selv benytte teknologien til at overvåge sin partner, men han kan også pålægge sin partner at bidrage til sin egen overvågning ved minutiøst at skulle redegøre for sine handlinger og sin færden. Hvordan det går til, beskriver den amerikanske sociolog Evan Stark i bogen Coercive Control. How Men Entrap Women in Personal Life (Stark 2007). Ifølge Stark, der har haft stor indflydelse på den internationale voldsforskning og praksis, herunder også lovgivning, har man været for tilbøjelig til at fokusere på fysisk vold, som typisk også er blevet rangordnet i forhold til alvorsgrad. Man har haft fokus på den fysiske vold forstået som enkeltstående hændelser, og man har været tilbøjelig til at adskille fysisk og psykisk vold, altså splitte den voldelige virkelighed op i distinkte voldsformer.

Men, hævder Stark, vold i parforhold er i langt de fleste tilfælde karakteriseret ved tvangsbaseret kontrol, ${ }^{6}$ det vil sige, at udøveren er drevet af et ønske om ikke bare at kontrollere partnerens adfærd, men også hendes tanker og følelser. Tvangsbaseret kontrol er et strategisk handlingsmønster, der er karakteriseret ved hyppige fysiske overgreb og seksuel tvang, men på et „beskedent“ niveau, hvor skadestue og politi typisk ikke involveres. Og det sker i kombination med taktiske udspil, der intimiderer, nedgør, isolerer og kontrollerer partneren.

Ifølge Stark kan en voldsudøver fremkalde lammende frygt, underkastelse og afhængighed hos offeret med meget lidt eller slet ingen fysisk vold. Han taler om gidsellignende tilstande og tilsvarende frygt, mikroovervågning og -regulering og en følelse af at være isoleret, fanget og fastlåst - en form for fysisk og psykisk frihedsberøvelse (jf. Lundgren 1993, 1998). Det kan også forklare, hvordan det går til, at voldsofferet bidrager til selvovervågning og selvundertrykkelse.

Stark omtaler tvangsbaseret kontrol som en kønsstrategi (Stark 2007:232), der rummer tre dimensioner: en kønsideologi, det vil sige grundlæggende forestillinger og værdier knyttet til, hvad det vil sige at være mand og kvinde i dag; en kønsteknologi, som er en samling af ressourcer, redskaber, teknikker og taktikker, der kan implementere disse forestillinger; og en handlingsplan, det vil sige 
en plan, der anvender denne teknologi i konkrete parforhold i overensstemmelse med forestillinger og præferencer. Kønsteknologien, forklarer Stark, handler om „the what and how of partner dominance“, altså, hvad der skal til for at undertrykke ens partner, og hvordan man griber det an. I Starks perspektiv er digital vold mod en partner altså blot en del af den kønsteknologi, der igen indgår som led i en overordnet kønsstrategi.

Den teknologiforståelse, der kommer til udtryk i Starks kønsstrategi, svarer til de overvejelser, antropologen Inger Sjørslev gør sig om teknologi under interviewet, der indleder dette temanummer af Tidsskriftet Antropologi:

Der skal være noget materielt, og der skal være nogle mennesker, der gør noget, og så skal der være noget viden, nogle idéer, nogle forestillinger bag. De ingredienser skal være til stede, for at man kan tale om noget som en teknologi, vil jeg mene (Sjørslev i Madsen \& Møhl 2020:16).

Stark og hans begreb tvangsbaseret kontrol er i løbet af de seneste år blevet almindelig kendt blandt både praktikere og forskere i Danmark. Men udbredelsen betyder også - og det er set før - at begrebet udvandes og undertiden bruges til noget andet, end det er tænkt. Herhjemme er der en tendens til at sætte lighedstegn mellem tvangsbaseret kontrol og psykisk vold i mere snæver forstand. ${ }^{7} \mathrm{Og}$ på den måde bidrager man faktisk til at adskille det, som Stark forsøger at få os til at forstå som et samlet hele, ${ }^{8}$ nemlig et kønsstrategisk voldsregime baseret på tvang og kontrol, hvor teknologien er designet til at modsvare individuelle kvinders agens og modstand. Ifølge Stark prøver voldsudøvere sig frem for at finde ud af, hvad der virker. De benytter den intime viden, de har fået adgang til, til at stramme grebet og give det et personligt og raffineret touch. Man kunne måske kalde det for kønsteknologisk innovation?

\section{Noter}

1. Alle danske kvindekrisecentre synes at have en beskrivelse af voldsformer på deres hjemmeside. Hvis man klikker på fanen „Hvad er vold?“, dukker voldsformerne op.

2. På Socialstyrelsens hjemmeside optræder digital vold ikke som selvstændigt opslagsord. Derimod kan man finde en beskrivelse af fænomenet under „Hvad er stalking?“. Her beskrives det som ,en form for psykisk vold, som består af uønsket og gentagen overvågning, forfølgelse og chikane" (Socialstyrelsen 2018).

3. Det gælder nok for Socialstyrelsen som for mange andre, at kønsneutralitet opfattes som en god ting, „, for er man neutral, vælger man ikke side og er ikke forudindtaget. En kønsneutral voldsforståelse ses derfor som det ansvarlige, afbalancerede og nuancerede udgangspunkt" (Sørensen 2019:11). Men hvis volden er et kønnet fænomen, må den nødvendigvis forstås i et kønsperspektiv. At se volden i et kønsperspektiv handler ikke om at vælge side. Det er hverken en kønsideologisk eller normativ tilgang. Det er en analytisk tilgang. 
4. Projektet var udbudt af Danner og TrygFonden og finansieret af TrygFonden.

5. Projektet var finansieret af Det Frie Forskningsråd, Samfund og Erhverv (FSE).

6. Jeg oversætter coercive control til tvangsbaseret kontrol (jf. Danneskiold-Samsøe, Mørck \& Sørensen 2019:61).

7. Forklaringen på det er muligvis, at Stark netop selv har fremhævet, at der har været for meget fokus på det fysiske aspekt af volden og især på den mere alvorlige fysiske vold, der fører til skader, der kan betyde inddragelse af politi og sundhedsvæsen. For hovedparten af vold i parforhold er ifølge Stark karakteriseret ved et fysisk voldsniveau, der er minimalt set fra både et juridisk og medicinsk synspunkt. Det betyder, at lovgivningen svigter voldsramte kvinder. Stark har af samme grund agiteret for en lovgivning på området, der i højere grad afspejler det generelle fænomen, som det faktisk tager sig ud.

8. Også sociologen Liz Kelly (1987) gør med begrebet „voldens kontinuum“ opmærksom på, at man ikke bør adskille voldsformer, der er forbundet, og at man ikke bør adskille erfaringer, der hører sammen. Begrebet kan bidrage til at fastholde sammenhængen mellem for eksempel seksuelle, fysiske, psykiske, økonomiske og for den sags skyld også digitale overgreb. Og det kan bidrage til at forstå den enkelte kvindes voldserfaringer - både de mindre og de mere „alvorlige“ - som forbundne og akkumulerede erfaringer over tid (se også Sørensen 2013).

\section{Litteratur}

Danneskiold-Samsøe, Sofie, Yvonne Mørck \& Bo Wagner Sørensen

2011 „Familien betyder alt“. Vold mod kvinder i etniske minoritetsfamilier. Frederiksberg: Frydenlund.

Danneskiold-Samsøe, Sofie, Yvonne Mørck \& Bo Wagner Sørensen

2019 Eresrelateret social kontrol. Teori og praksis i socialt arbejde. København: Akademisk Forlag.

EIGE, Det Europæiske Institut for Ligestilling mellem Mænd og Kvinder (EU-organ og EUagentur)

2017 Digital vold mod kvinder og piger. DOI:10.2839/898228. https://op.europa.eu/ da/publication-detail/-/publication/0986a0fa-beb7-11e7-a7f8-01aa75ed71a1/ language-da. Læst 9.3.2020.

Holmberg, Carin \& Viveka Enander

2004 Varför går hon? Om misshandlade kvinnors uppbrottsprocesser. Göteborg: Kabusa Böcker.

Jensen, Thomas Klose, Diana Bengtsen \& Emil Eusebius Olhoff-Jakobsen

2018 Digitale krænkelser på krisecentre: Vrede mænd sporer ekskonen med gps. https://www.dr.dk/nyheder/indland/digitale-kraenkelser-paa-krisecentre-vredemaend-sporer-eks-konen-med-gps. Læst 9.3.2020.

Johansen, Katrine Bindesbøl Holm, Tine Tjørnhøj-Thomsen \& Karin Helweg-Larsen 2013 Stalking i Danmark. En kortlægning af erfaringer, konsekvenser og støttebehov. København: Statens Institut for Folkesundhed, Syddansk Universitet.

Juul, Lena

2017 Digital vold er en voksende udfordring for kvindekrisecenter. Jydske Vestkysten 24.12. https://jv.dk/artikel/digital-vold-er-en-voksende-udfordring-forkvindekrisecenter-2017-12-24(2). Læst 9.3.2020. 
Jørgensen, Tanja Tambour

2013 Omfanget og karakteren af stalking. En befolkningsundersøgelse. København: Justitsministeriets Forskningskontor.

Kelly, Liz

1987

The Continuum of Sexual Violence. In: J. Hanmer \& M. Maynard (eds): Women, Violence and Social Control. Pp. 46-60. London: Macmillan Press.

Lundgren, Eva

1993 Det får da være grenser for kjønn. Voldelig empiri og feministisk teori.

Oslo: Universitetsforlaget.

1998 The Hand That Strikes and Comforts. Gender Construction and the Tension Between Body and Symbol. In: R.E. Dobash \& R.P. Dobash (eds): Rethinking Violence Against Women. Pp. 169-98. London: Sage Publications.

$2004 \quad$ Våldets normaliseringsprocess. Stockholm: ROKS.

Madsen, My \& Perle Møhl

2020 Teknologi, teknik, tekne, ting, t. En duelog mellem Inger Sjørslev og Lars Botin. Tidsskriftet Antropologi 81:7-24.

Nydahl, Kristine Lund

$2018 \quad$ Nye digitale muligheder skaber problemer for voldsramte kvinder. Fyens Stiftstidende 2.1. https://fyens.dk/artikel/nye-digitale-muligheder-skaberproblemer-for-voldsramte-kvinder-2018-1-2(2). Læst 9.3.2020.

Socialstyrelsen

2018 Hvad er stalking? https://socialstyrelsen.dk/voksne/vold-i-naere-relationer/videnom-vold/typer-af-vold/hvad-er-stalking. Læst 26.3.2020.

2019a Typer af vold. https://socialstyrelsen.dk/voksne/vold-i-naere-relationer/viden-omvold/typer-af-vold. Læst 26.3.2020.

2019b Årsstatistik 2018. Kvinder og børn på krisecenter. Odense: Socialstyrelsen.

2020 Voldsudsatte familier. Registeranalyse af Dialog mod Volds behandlingstilbud. Odense: Socialstyrelsen.

Stark, Evan

2007

Coercive Control. How Men Entrap Women in Personal Life. New York: Oxford University Press.

Sørensen, Bo Wagner

2013 Voldens kontinuum og kvinders voldserfaringer. Sosiologi i dag 43(4):69-93.

2019 Den kønsneutrale voldsforståelse. Social Kritik 158:9-12.

Sørensen, Bo Wagner, Sofie Danneskiold-Samsøe \& William Østerby Sørensen (red.)

Kønsneutral voldsforståelse. Temanummer, Social Kritik 158. 